\title{
Erratum to: ACP, volume 33, issues 1, 2, 3-4 and 5-6, 2010
}

\author{
The Editor-in-Chief
}

Published online: 20 August 2011

(C) International Society for Cellular Oncology 2011

\section{The Editors}

Erratum to: Cell Oncol. (2011) DOI 10.1007/s13402-0110027-7, 10.1007/s13402-011-0030-z, 10.1007/s13402-0110032-x, 10.1007/s13402-011-0035-7, 10.1007/s13402-0110036-6, 10.1007/s13402-011-0037-5, 10.1007/s13402-0110038-4, 10.1007/s13402-011-0039-3

The following articles are being re-published in their entirety without any changes in Cellular Oncology. They were previously published in Analytical Cellular Pathology, volume 33, 2010.

These articles were submitted to the journal Cellular Oncology, but due to some misunderstanding and a title change during 2010, they were published in Analytical Cellular Pathology and not Cellular Oncology.

In order to address this situation, and with the full agreement of the publishers concerned and of the authors, the articles are being re-published in the journal Cellular Oncology as originally intended. The articles re-published

The online version of the original article can be found at http://dx.doi.org/ 10.1007/s13402-011-0027-7, http://dx.doi.org/10.1007/s13402-0110030-z, http://dx.doi.org/10.1007/s13402-011-0032-x, http://dx.doi.org/ 10.1007/s13402-011-0035-7, http://dx.doi.org/10.1007/s13402-0110036-6, http://dx.doi.org/10.1007/s13402-011-0037-5, http://dx.doi.org/ 10.1007/s13402-011-0038-4, 10.1007/s13402-011-0039-3.

The Editor-in-Chief $(\bowtie)$

Department of Pathology, VU University Medical Center, PO Box 7057, 1007 MB Amsterdam, the Netherlands

e-mail: cellularoncology@vumc.nl in Cellular Oncology, Volume 34, 2011, should be considered the correct version of record.

Published in Analytical Cellular Pathology volume 33, 2010 as:

M. Grimm, M. Lazariotou, S. Kircher, A. Höfelmayr, C.T. Germer, B.H.A. von Rahden, Tumor necrosis factor- $\alpha$ is associated with positive lymph node status in patients with recurrence of colorectal cancer indications for anti-TNF- $\alpha$ agents in cancer treatment, Anal Cell Pathol 33(3-4), 151163 (2010), IOS Press

A. Fariña-Sarasqueta, M.J.E.M. Gosens, E. Moerland, I. van Lijnschoten, V.E.P.P. Lemmens, G.D. Slooter, H. J.T. Rutten, A.J.C. van den Brule, TS gene polymorphisms are not good markers of response to 5-FU therapy in stage III colon cancer patients, Anal Cell Pathol 33(1), 1-11 (2010), IOS Press

Timo Gaiser, Lissa Berroa-Garcia, Ralf Kemmerling, Aparajita Dutta, Thomas Ried, Kerstin HeselmeyerHaddad, Automated analysis of protein expression and gene amplification within the same cells of paraffinembedded tumour tissue, Anal Cell Pathol 33(2), 105-112 (2010), IOS Press

Awal M. Hadi, Koen T.B. Mouchaers, Ingrid Schalij, Katrien Grunberg, Gerrit A. Meijer, Anton VonkNoordegraaf, Willem J. van der Laarse and Jeroen A.M. Beliën, Rapid quanti-fication of myocardial fibrosis: a new macro-based automated analysis, Anal Cell Pathol 33(5-6), 257-269 (2010), IOS Press 
Elisabeth J. Shaw, Brian Haylock, David Husband, Daniel du Plessis, D. Ross Sibson, Peter C. Warnke and Carol Walker, Gene expression in oligodendroglial tumors, Anal Cell Pathol 33(2), 81-94 (2010), IOS Press

Ana Flávia Costa, Albina Altemani, Hedy Vékony, Elisabeth Bloemena, Florentino Fresno, Carlos Suárez, José Luis Llorente, Mario Hermsen, Genetic profile of adenoid cystic carcinomas (ACC) with high-grade trans-formation versus solid type, Anal Cell Pathol 33(5-6), 217-228 (2010), IOS Press

Anna G. Antonacopoulou, Konstantina Floratou, Vasiliki Bravou, Anastasia Kottorou, Fotinos-Ioannis Dimitrakopoulos, Stella Marousi, Michalis Stavropoulos, Agelos K. Koutras, Chrisoula D. Scopa, Haralabos P. Kalofonos, The survivin -31 snp in human colorectal cancer correlates with survivin splice variant expression and improved overall survival, Anal Cell Pathol 33(5-6), 177-189 (2010)

S. Marchán, S. Pérez-Torras, A. Vidal, J. Adan, F. Mitjans, N. Carbó and A. Mazo, Dual effects of $\beta 3$ integrin subunit expression on human pancreatic cancer models, Anal Cell Pathol 33(5-6), 191-205 (2010)

Reprinted in Cellular Oncology volume 34, issue 4, 2011 as:

M. Grimm, M. Lazariotou, S. Kircher, A. Höfelmayr, C.T. Germer, B.H.A. von Rahden, Tumor necrosis factor- $\alpha$ is associated with positive lymph node status in patients with recurrence of colorectal cancer indications for anti-TNF- $\alpha$ agents in cancer treatment, Cell Oncol. 34(4), 315-326 (2011)

A. Fariña-Sarasqueta, M.J.E.M. Gosens, E. Moerland, I. van Lijnschoten, V.E.P.P. Lemmens, G.D. Slooter, H. J.T. Rutten, A.J.C. van den Brule, TS gene polymorphisms are not good markers of response to 5-FU therapy in stage III colon cancer patients, Cell Oncol. 34(4), 327-335 (2011)

Timo Gaiser, Lissa Berroa-Garcia, Ralf Kemmerling, Aparajita Dutta, Thomas Ried, Kerstin Heselmeyer-Haddad, Automated analysis of protein expression and gene amplification within the same cells of paraffin-embedded tumour tissue, Cell Oncol. 34(4), 337-342 (2011)

Awal M. Hadi, Koen T.B. Mouchaers, Ingrid Schalij, Katrien Grunberg, Gerrit A. Meijer, Anton Vonk-Noordegraaf, Willem J. van der Laarse and Jeroen A.M. Beliën, Rapid quanti-fication of myocardial fibrosis: a new macro-based automated analysis, Cell Oncol. 34(4), 343-354 (2011)

Elisabeth J. Shaw, Brian Haylock, David Husband, Daniel $\mathrm{du}$ Plessis, D. Ross Sibson, Peter C. Warnke and Carol Walker, Gene expression in oligodendroglial tumors, Cell Oncol. 34(4), 355-367 (2011)

Ana Flávia Costa, Albina Altemani, Hedy Vékony, Elisabeth Bloemena, Florentino Fresno, Carlos Suárez, José Luis Llorente, Mario Hermsen, Genetic profile of adenoid cystic carcinomas (ACC) with high-grade transformation, Cell Oncol. 34(4), 369-379 (2011)

Anna G. Antonacopoulou, Konstantina Floratou, Vasiliki Bravou, Anastasia Kottorou, Fotinos-Ioannis Dimitrakopoulos, Stella Marousi, Michalis Stavropoulos, Agelos K. Koutras, Chrisoula D. Scopa, Haralabos P. Kalofonos, The survivin -31 snp in human colorectal cancer correlates with survivin splice variant expression and improved overall survival, Cell Oncol. 34(4), 381-391 (2011)

S. Marchán, S. Pérez-Torras, A. Vidal, J. Adan, F. Mitjans, N. Carbó and A. Mazo, Dual effects of $\beta 3$ integrin subunit expression on human pancreatic cancer models, Cell Oncol. 34(4), 393-403 (2011) 